\title{
Oilfield Water and Favorable Petroleum Exploration Targets for the Triassic Baikouquan Formation in the Slope of Mahu Depression, Junggar Basin
}

\author{
Huifei Tao $\mathbb{D}^{1}{ }^{1}$ Yongqiang Qu, ${ }^{2}$ Tao $\mathrm{Wu}^{3}$ and Bingbing Liu ${ }^{1,4}$ \\ ${ }^{1}$ Lanzhou Center for Oil and Gas Resources, Northwest Institute of Eco-Environment and Resources, Chinese Academy of Sciences, \\ Lanzhou 730000, China \\ ${ }^{2}$ Northwest Branch of PetroChina Research Institute of Petroleum Exploration and Development, Lanzhou 100083, China \\ ${ }^{3}$ Research Institute of Exploration and Development, PetroChina Xinjiang Oilfield Company, Karamay, China \\ ${ }^{4}$ University of Chinese Academy of Sciences, Beijing, China
}

Correspondence should be addressed to Huifei Tao; taohuifei2018@lzb.ac.cn

Received 26 December 2020; Revised 19 April 2021; Accepted 19 May 2021; Published 29 May 2021

Academic Editor: Lei Wang

Copyright (C) 2021 Huifei Tao et al. This is an open access article distributed under the Creative Commons Attribution License, which permits unrestricted use, distribution, and reproduction in any medium, provided the original work is properly cited.

In this paper, we attempt to clarify the relationships between oilfield water and hydrocarbon distribution of the Triassic Baikouquan Formation, in the slope zone of Mahu depression, Junggar Basin, NW China, based on oilfield water mineralization degrees, diagenesis analysis, formation pressure coefficients, burial history, and thermal evolution processes. The results show that the study area can be divided into four zones according to the mineralization degrees, that is, (1) zone I: $\mathrm{NaHCO}_{3}+\mathrm{Na}_{2} \mathrm{SO}_{4}$ type water with residual intergranular pores, porosity usually higher than $10 \%$. The strata of zone I are generally buried shallow and influenced by leaching from atmospheric precipitation. This area contains normal edge and bottom water and has normal formation pressure coefficients (average 1.12); (2) zone II: $\mathrm{CaCl}_{2}$ type water with mainly compaction diagenesis, porosity usually less than $7 \%$ and high formation pressure coefficients (average 1.41); (3) zone III: $\mathrm{NaHCO}_{3}+\mathrm{CaCl}_{2}$ type oilfield water with mainly feldspar dissolution diagenesis, porosity usually greater than $9 \%$ and high formation pressure coefficients (average 1.53); and (4) zone IV: $\mathrm{CaCl}_{2}$ type water, mainly compacted diagenesis with a few intergranular and feldspar dissolved pores, and high formation pressure coefficients (average 1.58). The mineralization degrees of the oilfield water in zone II, III, and IV are relatively high. The appearance of $\mathrm{NaHCO}_{3}$ type water in the deeply buried areas is usually related to oil and gas charging. Therefore, within the strata, deeply-buried areas (e.g., zone III), where $\mathrm{NaHCO}_{3}$ type water has been developed, are favorable targets for oil and gas exploration.

\section{Introduction}

Oilfield water is an important part of the fluid system in oil and gas reservoirs. Its formation and movement are closely related to oil and gas generation and migration, as well as to the formation, preservation, and destruction of the oil or gas reservoir [1-5]. The study of oilfield water provides an effective way to investigate regional oil and gas exploration and development [6]. Researchers can assess the migration, accumulation, and preservation conditions of the oil and gas according to the hydrochemical data obtained from the water $[7,8]$.
Oilfield water is generally classified based on the combination of $\mathrm{Cl}^{-}, \mathrm{SO}_{4}{ }^{2-}, \mathrm{HCO}^{3-}, \mathrm{Na}^{+}\left(\mathrm{K}^{+}\right), \mathrm{Ca}^{2+}$, and $\mathrm{Mg}^{2+}$ ions $[5,8,9]$. According to the classification scheme of Suling, oilfield water usually is divided into four types: sodium sulfate $\left(\mathrm{Na}_{2} \mathrm{SO}_{4}\right)$ type, sodium bicarbonate $\left(\mathrm{NaHCO}_{3}\right)$ type, magnesium chloride $\left(\mathrm{MgCl}_{2}\right)$ type, and calcium chloride $\left(\mathrm{CaCl}_{2}\right)$ type [9]. In general, water in the upper section of the oil field profile is mainly sodium bicarbonate type. With buried depth increasing of the strata, the water type becomes magnesium chloride type and finally calcium chloride type [9].

The reservoirs for the Triassic Baikouquan Formation in the slope of Mahu depression, NW Junggar Basin contain 
abundant oil and gas with proven geological reserves reached 110 million tons [10]. The reservoirs for the Baikouquan Formation are characterized by a highly nonuniform distribution, low porosity and permeability (porosity and permeability are generally between $7.5 \%-16 \%$ and $0.05-43.9 \mathrm{mD}$, respectively) [11]. Therefore, it is a big challenge to find high-quality oil and gas enriched reservoirs in the slope of Mahu depression, NW Junggar Basin. In this work, we analyze the chemical characteristics of the oilfield water, the development characteristics of the diagenetic traps, and the charging history of oil and gas reservoirs. We then discuss the distribution relationships between oilfield water and oil and gas reservoirs. Finally, the oil and gas exploration targets will be proposed. This study provides suggestions for oil and gas exploration in the slope zone of Mahu depression and is also a useful reference for oil and gas exploration in some similar basins.

\section{Geological Background}

The Mahu depression is a secondary tectonic unit in the Junggar Basin and is located at the northwest margin of the Basin, bordering the Zayir and Halaalate Mountains in the west and north, and connected with the Zhongguai uplift in the south, and with the Dabasong and Xiayan uplifts in the southeast. It covers an area of about 5000 square kilometers (Figures 1(a) and 1(b)). The tectonic framework of the Mahu depression formed in the Early Cretaceous and is characterized by a gentle northwest to southeast trending monoclinic dumping relief, with a locally developed low amplitude fault slope break zone, or nose structure [12]. The fault system of the Mahu depression is well developed because of the multiple stages of tectonic activity from the late Paleozoic to the Neozoic. These faults are the main channels for oil and gas migration from the hydrocarbon source rock to the reservoirs. In addition, these faults improve the permeability of the reservoirs and are beneficial for the development of secondary pores [13-15].

The formations of the Late Paleozoic to Mesozoic are well developed from the bottom to the top in the Mahu depression. The Triassic Baikouquan Formation is a set of clastic rock with a thickness of 100-250 m. The lithology of the Baikouquan Formation is coarse at the bottom and fine at the top. The bottom part of the Baikouquan Formation is mainly composed of thick conglomerate and sandy conglomerate, with a small amount of mudstone. The upper part of the Baikouquan Formation is characterized by mudstone with a few sandy conglomerates. Previous studies have suggested that the sedimentary facies of the Triassic Baikouquan Formation is a fan delta $[16,17]$. The colours of the rocks are mainly brown, green, and gray. The conglomerate and sand conglomerate are developed in the braided river channels of the delta plain and underwater channels of the delta front. The sorting of the conglomerate is poor, and the gravels are subrounded, with diameters of 2-45 $\mathrm{mm}[12,18]$.

\section{Samples and Methods}

Fifty-two oilfield water samples are collected from the Triassic Baikouquan Formation. The cation and anion concentrations of the oilfield water are analyzed by the ion chromatography system (ICS-2500, DIONEX Company). The estimated precision for the ion concentration is $0.1 \%-0.3 \%$. Then, the mineralization degrees of the oilfield water are calculated by adding all the concentrations of the ions. The results are presented in Figure 1 and Table 1 . The formation pressure coefficients are calculated by the formula: reservoir fluid pressure/hydrostatic pressure, and forty-nine data are obtained from the Xinjiang Oilfield Company. Thirty reservoir samples are studied by observing the thin sections under polarized microscope, and the petrology and pore structures are analyzed. The porosity and permeability of the reservoirs are provided by the Xinjiang Oilfield Company.

\section{Results}

4.1. Chemical Characteristics and Distribution of Oilfield Water. Oilfield water in the study area is mainly composed of $\mathrm{Cl}^{-}, \mathrm{K}^{+}, \mathrm{Na}^{+}, \mathrm{Ca}^{2+}, \mathrm{HCO}_{3}{ }^{-}, \mathrm{SO}_{4}{ }^{2-}$, and $\mathrm{Mg}^{2+}$ ions. The relative concentration of the ions, from high to low, is $\mathrm{Na}^{+}$ $\left.+\mathrm{K}^{+}\right)>\mathrm{HCO}_{3}{ }^{-}>\mathrm{Cl}^{-}>\mathrm{SO}_{4}{ }^{2-}>\mathrm{Mg}^{2+}$. Among the cationic components, the $\mathrm{Na}^{+}+\mathrm{K}^{+}$ion concentration is the highest with an average value of $6412.3 \mathrm{mg} / \mathrm{L}$. The $\mathrm{Ca}^{2+}$ concentration is median with an average value of $775.0 \mathrm{mg} / \mathrm{L}$, whereas the $\mathrm{Mg}^{2+}$ concentration is the lowest. Among the anions, the $\mathrm{HCO}_{3}{ }^{-}$concentration varies from 35.4 to $118954.7 \mathrm{mg} / \mathrm{L}$ with an average value of $6241.4 \mathrm{mg} / \mathrm{L}$. The average concentration of $\mathrm{Cl}^{-}$is $6179.0 \mathrm{mg} / \mathrm{L}$, which is slightly lower than the concentration of $\mathrm{HCO}_{3}{ }^{-}$. The $\mathrm{SO}_{4}{ }^{2-}$ concentration is relatively low with an average value of $589.6 \mathrm{mg} / \mathrm{L}$. There is also a very small amount of $\mathrm{CO}_{3}{ }^{2-}$ in the oilfield water.

The study area can be divided into four zones according to the mineralization degrees of oilfield water (Figure 1(b)). At the northern edge of the study area (zone I), the average mineralization degree is $3000 \mathrm{mg} / \mathrm{L}$. From the northern edge to the center of the basin, the mineralization degree increases. The average mineralization degrees for other three zones are $15000 \mathrm{mg} / \mathrm{L}$ (zone II), $8000 \mathrm{mg} / \mathrm{L}$ (zone III), and $10000 \mathrm{mg} / \mathrm{L}$ (zone IV), respectively (Table 1 ). The ionic compositions and types of the oilfield water are also different among the four zones. The oilfield water in the northern marginal zone (zone I) mainly contains $\mathrm{Na}^{+}, \mathrm{HCO}_{3}{ }^{-}, \mathrm{SO}_{4}{ }^{2-}, \mathrm{K}^{+}, \mathrm{Ca}^{2+}, \mathrm{Mg}^{2+}$, and $\mathrm{Cl}^{-}$. The former three ions are the dominant components, forming $\mathrm{NaHCO}_{3}+\mathrm{Na}_{2} \mathrm{SO}_{4}$ type oilfield water. The $\mathrm{Ca}^{2+}$, $\mathrm{Na}^{+}$, and $\mathrm{Cl}^{-}$ions are the dominant components in the slope area and the center of the study area, forming two $\mathrm{CaCl}_{2}$ type oilfield water zones (zone II and zone IV), but the mineralization degrees between zone II and zone IV are different. And the area that lies between zone II and zone IV is $\mathrm{NaH}$ $\mathrm{CO}_{3}+\mathrm{CaCl}_{2}$ type oilfield water zone (zone III).

4.2. Characteristics of Diagenetic Trap. The main diagenesis types of the Triassic Baikouquan Formation in the study area are cementation, compaction, and dissolution $[16,19,20]$ (Figure 2). The diagenesis types are different in different areas. In the northern marginal area (zone I), the shallow burial depth and relatively weak compaction mean that residual intergranular pores developed in the reservoir, and the average porosity is greater than $10 \%$ (Figure $2(\mathrm{a})$ ). From the 


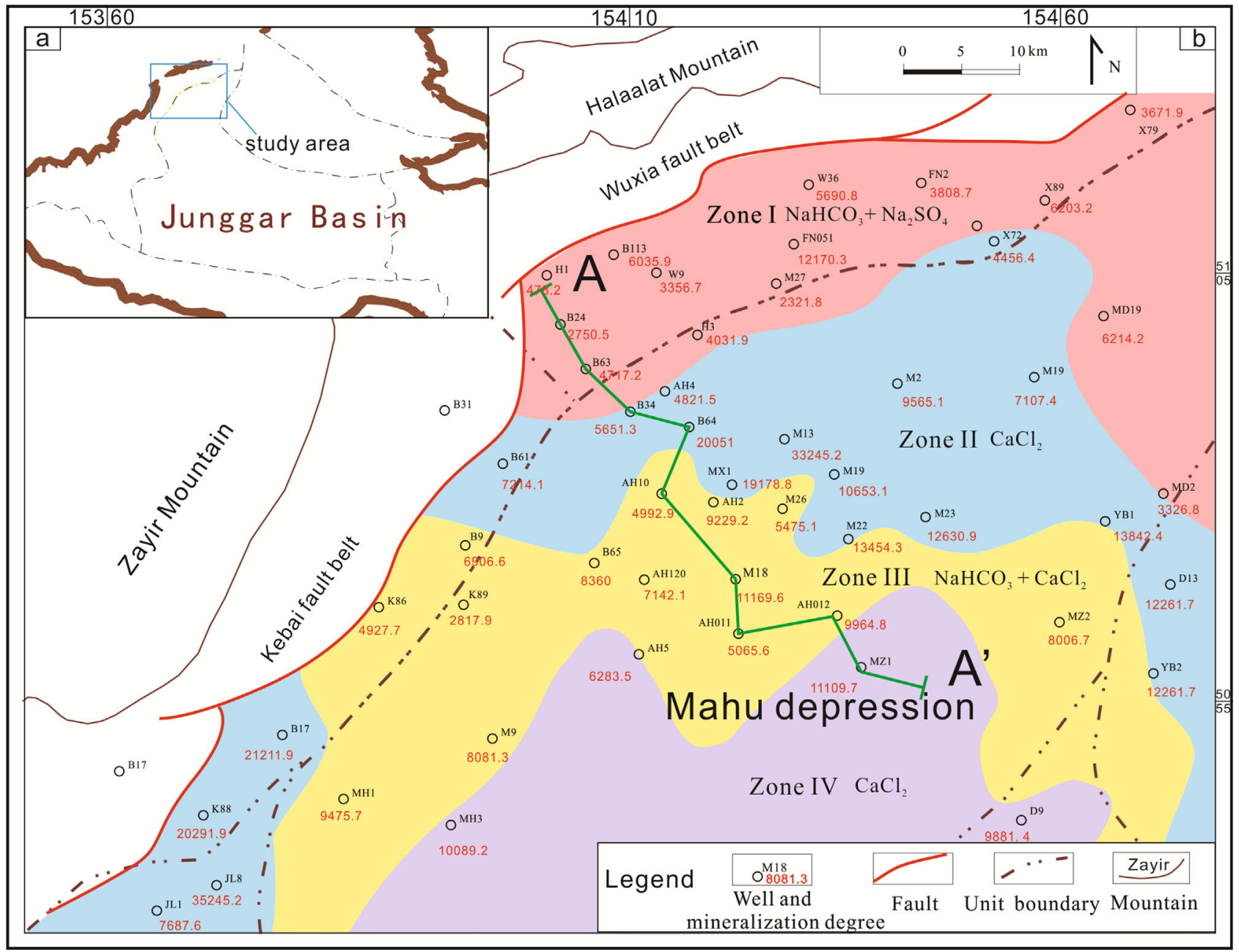

Figure 1: (a) Location of the study area. (b) Geological setting of the Mahu depression with zones for different oilfield water types.

TABle 1: Salinity and pressure coefficients for the Triassic Baikouquan Formation in the study area.

\begin{tabular}{|c|c|c|c|c|c|c|}
\hline \multirow{2}{*}{ Zone } & \multicolumn{3}{|c|}{ Salinity $(\mathrm{mg} / \mathrm{L}$, well number $=52)$} & \multicolumn{3}{|c|}{ Pressure coefficient $($ well number $=49)$} \\
\hline & Min. & Max. & Average & Min. & Max. & Average \\
\hline Zone I & 478.2 & 12170.3 & 3000 & 1.00 & 1.23 & 1.12 \\
\hline Zone II & 7107.4 & 35245.2 & 15000 & 1.31 & 1.57 & 1.41 \\
\hline Zone III & 4992.9 & 13454.3 & 8000 & 1.35 & 1.90 & 1.53 \\
\hline Zone IV & 6283.6 & 11109.6 & 10000 & 1.42 & 1.95 & 1.58 \\
\hline
\end{tabular}

margin to the center of the basin, the compaction diagenesis increases with the increase of burial depth. In zone II, the main diagenesis type is compaction (Figure 2(b)). The reservoir is compacted with a few dissolution pores, and the porosity is about $7 \%$. In zone III, although the depths of the strata are greater than in zone II, the pores are more developed due to the dissolution of feldspar (Figure 2(c)). Thus, the porosity of the reservoir in zone III increases to above 9\%. In zone IV, the reservoir is mainly compacted. However, some dissolution pores have developed in the reservoirs, e.g., in well D9, which shows intergranular dissolved pore and feldspar dissolution pores, with porosity greater than $9 \%$ (Figure $2(\mathrm{~d})$ ). A dis- solution depth line has formed between zone I and zone II according to the development of reservoir dissolution. The northern side of the dissolution depth line (zone I) is mainly composed of primary residual intergranular pores, and the oilfield water here has low salinity. In zone I, the burial depth of the strata is shallow and may be affected by atmospheric precipitation, and this area therefore belongs to an open zone of oilfield water. On the southern side of the dissolution depth line (zones II, III, and IV), the formations are deeply buried. And compaction and dissolution diagenesis are the main factors affecting the physical properties of the reservoir. The oilfield water in zones II, III, and IV comes from sedimentary-buried 


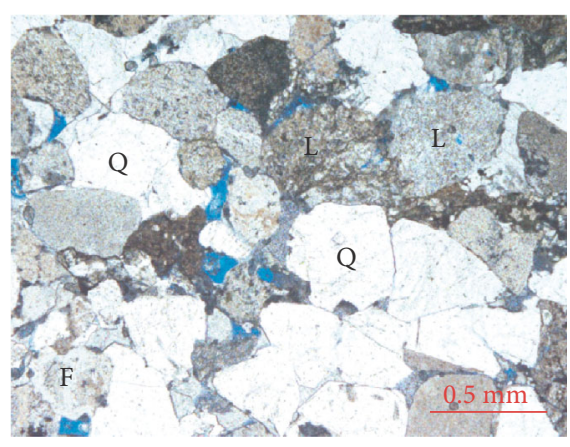

(a)

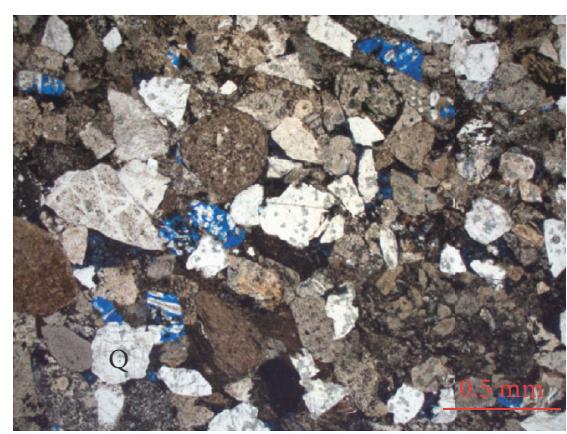

(c)

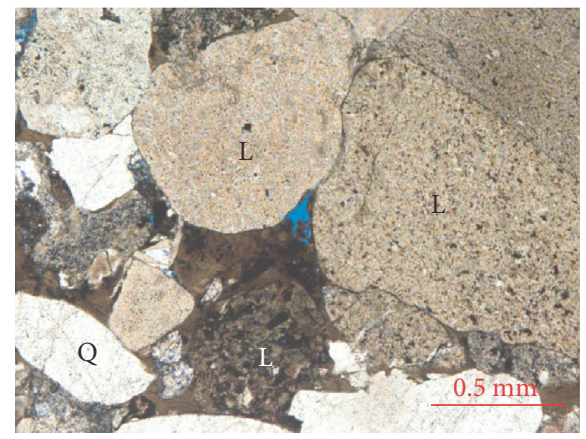

(b)

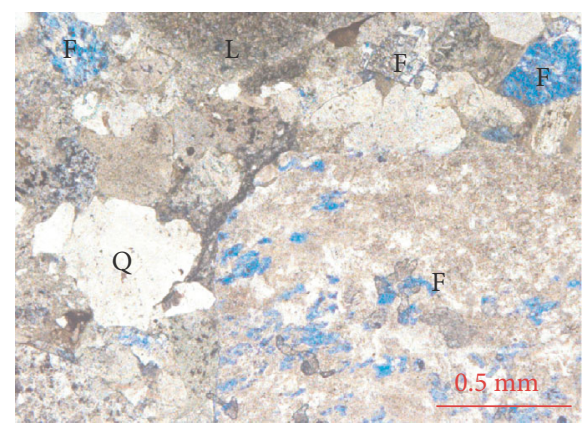

(d)

FIGURE 2: Pore types for different diagenetic phases: L: lithic clast; Q: quartz; F: feldspar. (a) Well X89, 2477.27 m: residual intergranular pore and dissolved pore development, primarily line contact between particles and surface crack development for quartz particles. (b) Well M23, $3641.29 \mathrm{~m}$ : strong compacted diagenesis, line contact between particles with a few residual intergranular pore. (c) Well MZ2, $4201.94 \mathrm{~m}$ : feldspar dissolved into intragranular pores. (d) Well M18, $3852.55 \mathrm{~m}$ : line contact between particles and feldspar dissolution.

water, which is highly mineralized and belongs to the sealing zone for the oilfield water.

Under the influence of cementation, compaction, and dissolution diagenesis, the reservoir becomes tight and forms the diagenetic trap [21]. The above analysis reflects the fact that zone II has a compacted reservoir and low physical properties, and thus, can be the cap rock for zone III and zone IV, forming regional lithologic traps.

\subsection{Formation Pressure and Hydrocarbon Charging History.} The formation pressure coefficient $\left(a_{p}\right)$ is calculated as the ratio of the formation pressure $\left(P_{p}\right)$ to the hydrostatic pressure $\left(P_{h}\right)$. The formation pressure coefficient is usually used to evaluate whether the formation pressure is normal or abnormal. In the petroleum reservoir system, normal pressure coefficients are usually in the range of $0.8-1.2$. The values of formation pressure coefficient above 1.2 indicate abnormally high formation pressure, and values below 0.8 indicate abnormally low formation pressure [18]. The formation pressure coefficients for the Triassic Baikouquan Formation in the study area range from 1.0 to 1.95 and have an average of 1.33 (Table 1). The formation pressure coefficients for zone I are relatively low, with an average value of 1.12 , which shows that this zone belongs to a normal formation pressure area. In the slope and central parts of the study area (zones II, III, and IV), the formation pressure coefficients are generally greater than 1.3, and the highest value is 1.95 . Thus, the slope and central parts of the study area are abnormally highpressure zones.

Previous researches reflected that the Triassic Baikouquan Formation experienced three stages of oil and gas filling [15]. The periods of the oil and gas filling are before the late Triassic, in the early Jurassic, and in the early Cretaceous. Before the late Triassic, the burial depth of the Baikouquan Formation was shallow and traps failed to form, but the residual bitumens in the strata provided evidence of oil and gas filling [15]. The strata burial history showed that the burial depth of the Triassic Baikouquan Formation was about 800-1600 m during the early Jurassic, the second stage of oil and gas filling [15]. Due to the relatively shallow burial depth, the pores are mainly primary pores with a small number of secondary pores. The reservoir rocks in the Baikouquan Formation experienced the early stages of diagenesis during the early Jurassic [18]. Previous studies suggest that a largescale dissolution reaction temperature for albite and $\mathrm{K}$ feldspar is $80-140^{\circ} \mathrm{C}[22,23]$. According to the burial and thermal evolution history of the strata in the study area (Figure 3), when the burial depth of the Baikouquan Formation exceeded $2300 \mathrm{~m}$, the paleo-temperature may have reached $80^{\circ} \mathrm{C}[16,20]$. Therefore, a small proportion of the dissolution pores in the reservoir rocks is related to the dissolution of calcium feldspar, caused by precipitation or organic acid during the early Jurassic, but the K-feldspar and albite did not reach the temperature required for large-scale dissolution [15, 22, 24, 25]. In the early Cretaceous, the Baikouquan Formation was buried at a depth 


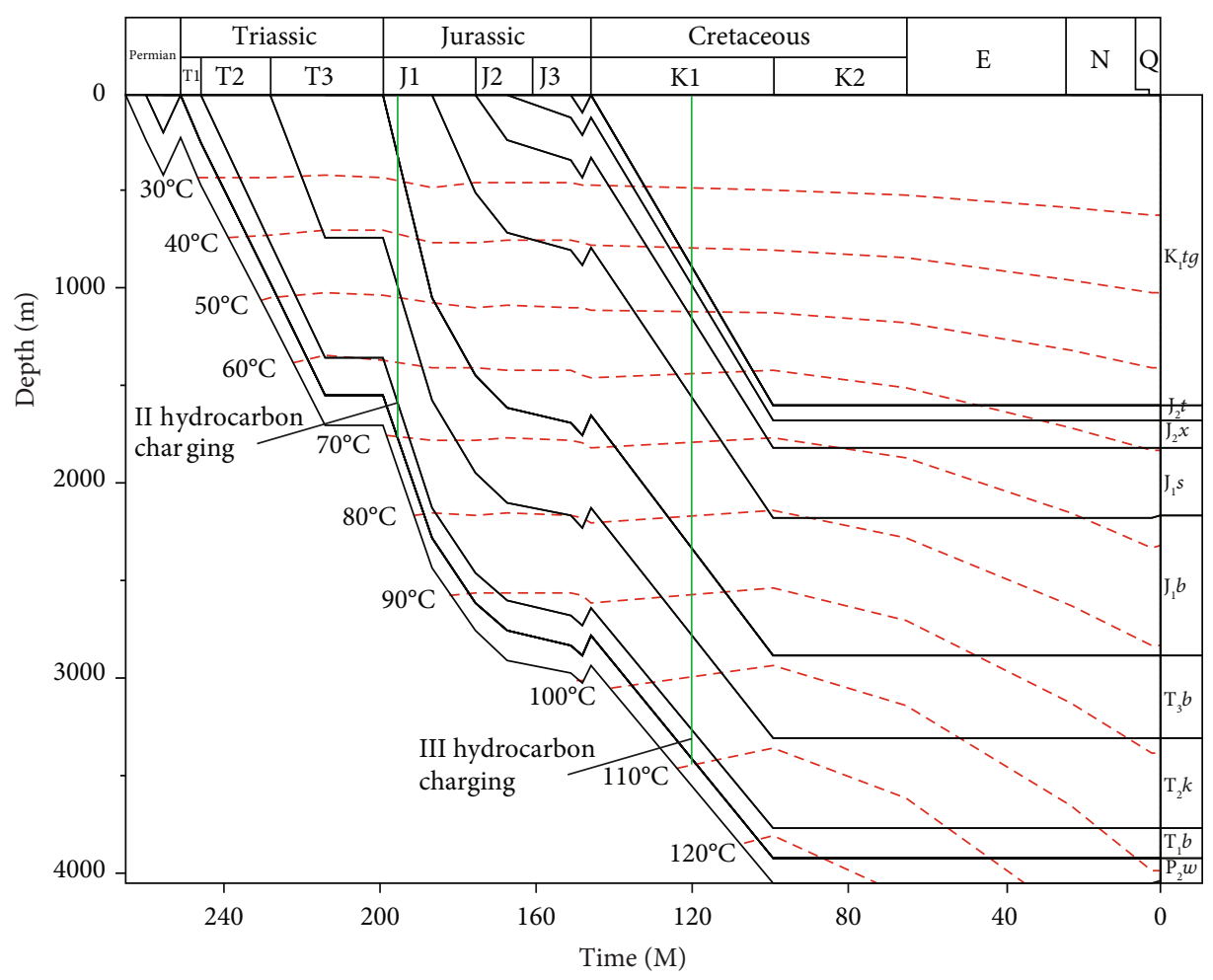

Figure 3: Burial and thermal chart of the well M13, modified after Pan et al. [20].

of 1400-3200 m. Previous studies suggest that the maximum strata depth affected by atmospheric precipitation is about $2000 \mathrm{~m}$ [20]. Therefore, with a burial depth of 2000-2300 m, the Baikouquan Formation was not affected by atmospheric precipitation leaching, at the same time as the K-feldspar and albite did not reach the large-scale dissolution reaction temperature [25]. Also during the early Cretaceous, the reservoirs entered the early diagenetic stage, so the compaction became stronger and formed a tight diagenetic belt. When the burial depth exceeded $2300 \mathrm{~m}$, a large number of feldspars experienced dissolution in the Baikouquan Formation, and the porosity and permeability of the reservoir increased significantly, which was favorable for oil and gas filling.

\section{Discussion}

5.1. Oilfield Water Characteristics and Hydrocarbon Distribution. The mineralization degrees and types of oilfield water are the results of hydrocarbon accumulation and diagenetic evolution. The mineralization of oilfield water, and the nonuniform distribution of different types of oilfield water in the horizontal and vertical directions, indicates the occurrence of diagenesis and the process of hydrocarbon accumulation $[1,19,26]$.

The oilfield water of the Triassic Baikouquan Formation in the study area can be divided into three types: $\mathrm{NaHCO}_{3}+-$ $\mathrm{Na}_{2} \mathrm{SO}_{4}, \mathrm{NaHCO}_{3}+\mathrm{CaCl}_{2}$, and $\mathrm{CaCl}_{2}$. The $\mathrm{Na}_{2} \mathrm{SO}_{4}$ oilfield water often develops in an open oxidation environment with shallow strata burial and can be affected by atmospheric precipitation leaching [25]. Due to continuous replenishment through atmospheric precipitation, the mineralization degree of $\mathrm{Na}_{2} \mathrm{SO}_{4}$ type oilfield water is usually low. The generation of $\mathrm{NaHCO}_{3}$ oilfield water is usually related to the dissolution of feldspar minerals during the processes of oil and gas filling [27]. The accompanying oil and gas filling means that the associated carbon dioxide enters the oilfield water to form $\mathrm{NaHCO}_{3}$ water with high salinity [28].

The oilfield water type in zone I is a combination of $\mathrm{NaH}$ $\mathrm{CO}_{3}+\mathrm{Na}_{2} \mathrm{SO}_{4}$. This type of oilfield water may form in two ways. The $\mathrm{CO}_{2}$ associated with the hydrocarbon charging process may enter the groundwater to form $\mathrm{NaHCO} 3$ type oilfield water, or the leaching effect of atmospheric precipitation may bring a large amount of $\mathrm{HCO}_{3}^{-}$and $\mathrm{SO}_{4}{ }^{2-}$ ions through the dissolution of surface minerals, and so form $\mathrm{NaHCO}_{3}+\mathrm{Na}_{2} \mathrm{SO}_{4}$ type water. The reservoir profile shows that the reservoir in zone I contains normal edge-bottom water (the water layer below the oil and gas layer) and a normal formation pressure coefficient (Figure 4(a) and Table 1), which supports the theory that zone I is located in a strata open environment.

$\mathrm{CaCl}_{2}$ type oilfield water is usually formed deeply underground, in a sealed, stagnant, reductive environment $[1,26$, 29]. The $\mathrm{CaCl}_{2}$ type water is widely developed in zones II, III, and IV, indicating that the oilfield water in the reservoirs of the Baikouquan Formation flowed inadequately. However, in zone III, in addition to $\mathrm{CaCl}_{2}$ type oilfield water, the $\mathrm{NaHCO}_{3}$ type oilfield water is also extensively developed, which probably indicates that zone III experienced massive oil and gas charging. In zone III, the depth of the strata exceeds $2300 \mathrm{~m}$, so these strata cannot be affected by atmospheric precipitation leaching, but the feldspars of the reservoirs may be massively dissolved at this depth [27]. The 


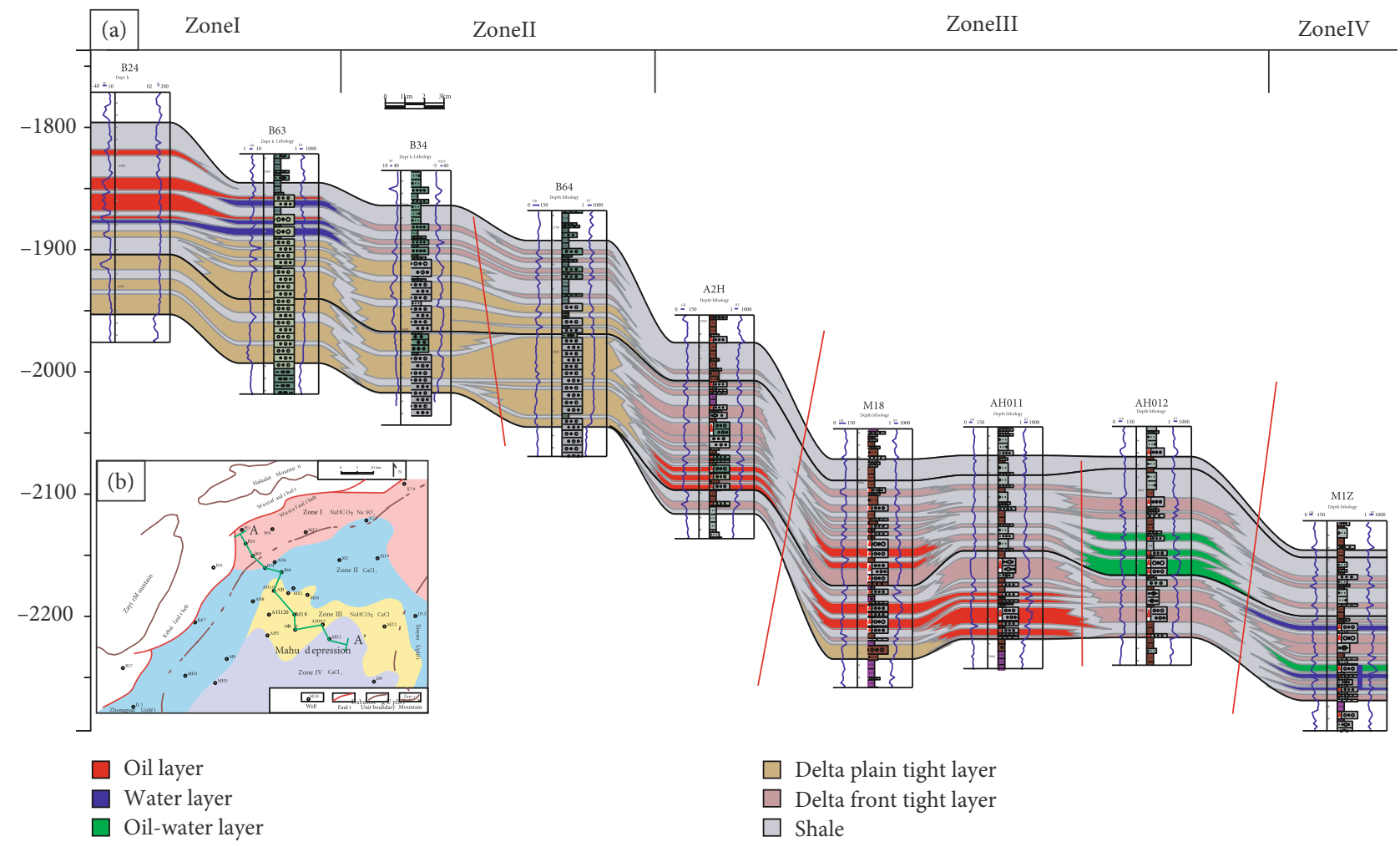

FIgURE 4: (a) Reservoir profile map for the Baikouquan Formation. (b) Location of the reservoir profile map in the study area (A-A').

dissolution of feldspar minerals improves the porosity and permeability of the reservoirs and is beneficial for oil and gas charging (Figure 4(a)). The $\mathrm{CO}_{2}$ that is associated with oil and gas charging forms the $\mathrm{NaHCO}_{3}$ type oilfield water. In zone II, the tight reservoir with low porosity and low permeability means that the oil and gas cannot be massively filled, so the oilfield water is mainly $\mathrm{CaCl}_{2}$ type with high mineralization degrees. In zone IV, the strata are buried much deeper than zone III, with a higher abnormal formation pressure, which may cause oil and gas filling to be insufficient. Therefore, the oil and gas layers are thin in zone IV (Figure 4(a)).

5.2. Favorable Exploration Targets. The mineralization degrees and types of the oilfield water in the study area are closely related to the filling and accumulation of oil and gas and are good indicators for oil and gas exploration. In zone I, the oilfield water has low mineralization degrees, normal edge-bottom water, normal formation pressure coefficients, and good physical reservoir properties. Due to buoyancy effects, oil and gas in zone I could migrate to high structural positions or lithological traps formed by the good sealing cap rock. Therefore, traps with good sealing cap rock in the higher parts of the formation structure and lithological traps are favorable targets for oil and gas exploration in zone I.

In the $\mathrm{CaCl}_{2}$ type oilfield water developed areas, the appearance of $\mathrm{NaHCO}_{3}$ is a good indicator for oil and gas charging. Because the $\mathrm{NaHCO}_{3}$ type oilfield water is usually formed by the $\mathrm{CO}_{2}$ inputting which is associated with the oil and gas charging. In zone III, the development of $\mathrm{NaHCO}_{3}$ type water is the result of oil and gas charging. Therefore, zone III is a favorable oil and gas exploration target area. In zones II and IV, a large amount of oil and gas charging may not have happened due to the reservoir being tight, or having insufficient charging power.

\section{Conclusions}

The mineralization degrees of oilfield water of the Triassic Baikouquan Formation vary greatly in the slope area of the Mahu depression. The mineralization degrees from the northern edge to the slope and center of the depression are average values of $3000 \mathrm{mg} / \mathrm{L}, 8000 \mathrm{mg} / \mathrm{L}, 10000 \mathrm{mg} / \mathrm{L}$, to $15000 \mathrm{mg} / \mathrm{L}$, thus, the study area is divided into four zones accordingly (I, II, III, and IV). The $\mathrm{NaHCO}_{3}+\mathrm{Na}_{2} \mathrm{SO}_{4}$ type oilfield water is mainly developed in zone I. The $\mathrm{CaCl}_{2}$ type oilfield water is developed in zones II and IV. And the $\mathrm{CaCl}_{2}+\mathrm{NaHCO}_{3}$ type oilfield water is developed in zone III.

The mineralization degrees and types of the oilfield water are closely related to the diagenesis evolution processes, and oil and gas charging. In the area where the Baikouquan Formation is buried at shallow depth (zone I), the diagenesis of the reservoir is weakly compacted, and the oilfield water is $\mathrm{NaHCO}_{3}+\mathrm{Na}_{2} \mathrm{SO}_{4}$ type with low mineralization degrees due to the influence of atmospheric precipitation leaching. In areas where the Baikouquan Formation is buried relatively deep (zones II, III, and IV), the diagenesis of the reservoirs is strongly compacted, and the oilfield water has high mineralization degrees and is mainly characterized by the development of $\mathrm{CaCl}_{2}$ type water. However, $\mathrm{NaHCO}_{3}$ type water is 
also developed in some regions (e.g., zone III), which probably is the result of $\mathrm{CO}_{2}$ inputting associated with oil and gas charging.

The diagenesis characteristics, reservoir profiles, and oilfield water types suggest that zone III has been experienced massive oil and gas charging, and this area is a favorable zone for oil and gas exploration. Zone I in the study area contains normal edge-bottom water and has normal formation pressure coefficients, thus, the favorable targets for oil and gas exploration in this area are structural traps or lithologic traps with good sealed cap-rock.

\section{Data Availability}

All data generated or analyzed during this study are included in this article.

\section{Conflicts of Interest}

The authors declare that they have no conflicts of interest.

\section{Acknowledgments}

This work was supported by funds from the Key Laboratory Project of Gansu Province (No. 1309RTSA041) and the Youth Innovation Promotion Association CAS (2016068).

\section{References}

[1] C. Cai, B. Mei, L. Wei, and F. Zeng, "Water-rock interaction in Tarim Basin: constraints from oilfield water geochemistry," Chinese Journal of Geochemistry, vol. 16, no. 4, pp. 289-303, 1997.

[2] C. Jiang, "Oil/water distribution and accumulation model of Putaohua oil layers in the west wing of Aobaota oilfield," Journal of Northeast Petroleum University, vol. 37, no. 5, pp. 42-48, 2013.

[3] W. Li, "Indication of natural gas migration and accumulation by three-dimensional fluorescence characteristics of gas-field waters: a case study of the Permian- Triassic in the centralwestern Sichuan Basin," Petroleum Exploration and Development, vol. 39, no. 2, pp. 202-211, 2012.

[4] Z. Lou, Z. Rong, Y. Lu, and C. Shang, "Hydrocarbon accumulation dynamics of Tahe Ordovician fractured-caved carbonate reservoir and types of oilfield water in Tahe oil field, Tarim Basin," Marine Origin Petroleum Geology, vol. 3, pp. 60-64, 2009.

[5] C. Serres-Piole, H. Preud'homme, N. Moradi-Tehrani, C. Allanic, and H. Jullia, "Water tracers in oilfield applications: guidelines," Journal of Petroleum Science and Engineering, vol. 98-99, no. 1, pp. 22-39, 2012.

[6] K. Li, C. Cai, H. He et al., "Origin of palaeo-waters in the Ordovician carbonates in Tahe oilfield, Tarim Basin: constraints from fluid inclusions and $\mathrm{Sr}, \mathrm{C}$ and $\mathrm{O}$ isotopes," Geofluids, vol. 11, no. 1, 86 pages, 2011.

[7] X. Lu, N. Yang, and J. Li, "Deep fluid activities and their effectiveness on hydrocarbon generation and accumulation in sedimentary basins," Marine Origin Petroleum Geology, vol. 11, no. 2, pp. 29-34, 2006.
[8] K. Yousif, K. Gans, E. Rowan et al., Chemical Composition of Formation Water in Shale and Tight Reservoirs, American Geophysical Union (AGU), 2019.

[9] L. G. Cai, Y. X. Qian, G. X. Liu, Y. Y. Han, and P. D. Zhang, "Origin of formation water in Tahe oilfield and adjacents," Petroleun Geology \& Experiment, vol. 24, no. 1, pp. 57-60, 2002.

[10] D. Zhi, "Discovery and hydrocarbon accumulation mechanism of quasi-continuous high-efficiency reservoirs of Baikouquan Formation in Mahu Sag, Junggar Basin," Xinjiang Petroleum Geology, vol. 4, pp. 373-382, 2016.

[11] X. Lu, D. Sun, X. Xie, X. Chen, and J. A. Shi, "Microfacies characteristics and reservoir potential of Triassic Baikouquan Formation, northern Mahu Sag, Junggar Basin, NW China," Journal of Natural Gas Geoscience, vol. 4, no. 1, pp. 47-62, 2019.

[12] N. Zou, D. Zhang, H. Qian, T. Wu, and J. A. Shi, "Main controlling factors of glutenite reservoir of fan delta in Mabei slope, Junggar Basin," Lithologic Reservoirs, vol. 28, no. 4, pp. 24-33, 2016.

[13] A. B. Frana, L. M. Araújo, J. B. Maynard, and P. E. Potter, "Secondary porosity formed by deep meteoric leaching: Botucatu eolianite, southern South America," AAPG Bulletin, vol. 87, no. 7, pp. 1073-1082, 2003.

[14] J. Huang, R. K. Zhu, D. J. Hou, and W. Ruan, "The new advances of secondary porosity genesis mechanism in deep clastic reservoir," Geological Science and Technology Information, vol. 26, no. 6, pp. 76-82, 2007.

[15] Y. Qu, G. Wang, K. Tan et al., "Controlling factors and distribution characteristics of the secondary pore reservoirs of the Triassic Baikouquan Formation in the Mahu Slope Area, Junggar Basin," Natural Gas Geoscience, vol. 26, Supplement 1, pp. 50-63, 2015.

[16] L. Kuang, Y. Tang, D. Lei, T. Wu, and J. Qu, "Exploration of fan-controlled large-area lithologic oil reservoirs of Triassic Baikouquan Formation in slope zone of Mahu Depression in Junggar Basin," China Petroleum Exploration, vol. 19, no. 6, pp. 14-23, 2014.

[17] Y. Tang, W. Guo, X. Wang, H. Bao, and H. Wu, “A new breakthrough in exploration of large conglomerate oil province in Mahu Sag and its implications," Xinjiang Petroleum Geology, vol. 40, no. 2, pp. 127-137, 2019.

[18] K. Tan, G. Wang, H. Luo, Y. Qu, L. Yin, and J. Chen, "Reservoir characteristics and controlling factors of the Triassic Baikouquan Formation in Mahu slope area, Junggar Basin," Lithologic Reservoirs, vol. 26, no. 6, pp. 83-88, 2014.

[19] J. Cao, W. Hu, X. Wang et al., "Diagenesis and elemental geochemistry under varying reservoir oil saturation in the Junggar Basin of NW China: implication for differentiating hydrocarbon-bearing horizons," Geofluids, vol. 15, no. 3, 420 pages, 2015.

[20] J. Pan, G. Wang, and Y. Qu, "Forming mechanism and characteristics of sandy conglomerate diagenetic trap: a case study of the Triassic Baikouquan Formation in Mahu Sag, Junggar Basin," Natural Gas Geoscience, vol. 26, Supplement 1, pp. 41-49, 2015.

[21] J. S. Enos and J. R. Kyle, "Diagenesis of the Carrizo Sandstone at Butler Salt Dome, East Texas Basin, U.S.A.: evidence for fluid-sediment interaction near halokinetic structures," Journal of Sedimentary Research, vol. 72, no. 1, pp. 68-81, 2002.

[22] S. Huang, J. Yang, and W. Zhang, "Experimental study of feldspar dissolution by acetic acid at different burial 
temperatures," Acta Sedimentologica Sinica, vol. 13, no. 1, pp. 7-17, 1995.

[23] R. C. Surdam, L. J. Crossey, E. S. Hagen, and H. P. Heasler, "Organic-inorganic and sandstone diagenesis," AAPG Bulletin, vol. 15, pp. 141-170, 1989.

[24] E. S. Chardon, F. R. Livens, and D. J. Vaughan, "Reactions of feldspar surfaces with aqueous solutions," Earth Science Reviews, vol. 78, no. 1-2, pp. 1-26, 2006.

[25] D. Emery, K. J. Myers, and R. Young, "Ancient subaerial exposure and freshwater leaching in sandstones," Geology, vol. 18, no. 12, pp. 1178-1181, 1990.

[26] C. A. Connolly, L. M. Walter, H. Baadsgaard, and F. J. Longstaffe, "Origin and evolution of formation waters, Alberta Basin, Western Canada sedimentary Basin. I. Chemistry," Applied Geochemistry, vol. 5, no. 4, pp. 375-395, 1990.

[27] U. Lundström and L.-O. Öhman, "Dissolution of feldspars in the presence of natural, organic solutes," European Journal of Soil Science, vol. 41, no. 3, pp. 359-369, 2010.

[28] M. Zha, Z. Chen, X. Zhu, N. Zhang, and Y. Zhang, "Petroleum accumulation system of Luliang area in Junggar Basin," Xinjiang Petroleum Geology, vol. 24, no. 2, pp. 97-99, 2003.

[29] I. Demir and B. Seyler, "Chemical composition and geologic history of saline waters in Aux Vases and Cypress Formations, Illinois Basin," Aquatic Geochemistry, vol. 5, no. 3, pp. 281311, 1999. 